\title{
An Evaluation of the Structure of Tropical Intraseasonal Oscillations in Three General Circulation Models
}

\author{
By Chung-Kyu Park \\ Centel Federal Services Corporation NASA/Goddard Space Flight Center, Greenbelt, MD 20771
}

David M. Straus

Center for Ocean-Land-Atmosphere Interactions, Department of Meteorology

University of Maryland, College Park, MD 20742

Ka-Ming Lau

Goddard Laboratory for Atmospheres NASA/Goddard Space Flight Center, Greenbelt, MD 20771

(Manuscript received 3 October 1989, in revised form 9 April 1990)

\begin{abstract}
Low-frequency oscillations appearing in three GCM seasonal cycle integrations are compared with the analyses of the European Centre for Medium-Range Weather Forecasts (ECMWF). All three models have the same resolution: 4 degrees latitude by 5 degrees longitude, with 9 levels. The GLAS GCM simulates a realistic eastward propagation of the 30-60 day oscillation in the tropical upperlevel divergent flow. The eastward travelling planetary scale structure becomes more stationary over the Indonesian region and accelerates over the central Pacific, as observed. In the GLA GCM, the oscillation propagates into the higher latitudes of both hemispheres as the waves leave the convective region. The presence of the eastward propagating oscillation is not obvious in the UCLA GCM. The wavenumber-frequency spectra of the $200 \mathrm{mb}$ velocity potential reveal that all the GCMs have a significantly weaker signal for eastward propagation in the 30-60 day range than the analyses. The spectrum for the GLAS GCM is dominated by 20-60 day periods, while the GLA GCM has a spectral peak around 20-30 days. There is a weak eastward propagating peak near 15 days in the UCLA GCM. The dominant phase speeds and the different vertical structures of the heating profiles in the GCMs are in general agreement with current theory involving the positive feedback between latent heating and moist static stability.

The composited patterns of the observations indicate that in the tropics a Kelvin wave-type structure is dominant near the center of the oscillation. The simulated winds are fairly realistic, although the meridional component is too strong, especially in the GLA GCM. The vertical structures of the zonal wind component and moisture suggest that a mobile wave-CISK (Lau and Peng, 1987) is an important mechanism in maintaining the intraseasonal oscillation in these GCMs. The vertical distribution of the moisture field further suggests that evaporation-wind feedback (Neelin, et al., 1987) may play a role in maintaining the eastward propagating tropical waves. The differences in the structure of the oscillation in the GLAS GCM and GLA GCM appear to be a consequence of the different numerical schemes used. The GCMs have preferred zones for diabatic heating, with a turn-on heating occurring when the rising branch of the intraseasonal oscillation passes over these convective regions.

All three GCMs fail to capture the detailed evolution in the different stages of the development and decay of the oscillation. The results suggest that an improvement in the boundary layer moisture processes may be crucial for a better simulation of the oscillation.
\end{abstract}

(C)1990, Meteorological Society of Japan 


\section{Introduction}

In recent years, there have been a large number of GCM simulation experiments of tropical intraseasonal oscillations. In general, these experiments fall into two categories. The first consists of experiments based on realistic boundary conditions such as observed sea surface temperatures, snow-ice distributions and topographic forcing (e.g. Lau and Lau, 1986; Hayashi and Golder, 1986, 1988, Geisler and Pitcher, 1988, Von Storch et al., 1987, Tokioka et al., 1988 among others). Many of the experiments in this category were not initially designed for the study of intraseasonal oscillations per se, but were motivated by more general climate concerns. The second category deals with simplified GCM experiments designed to analyze the basic mechanisms of intraseasonal oscillations using idealized boundary conditions i.e., aqua-planet experiments (Hayashi and Sumi, 1986, Swinbank et al., 1988) and swamp ocean experiments (Lau et al., 1988). Both categories have provided a rich source of information and testing grounds for validating theories of intraseasonal oscillations (e.g. Lau and Peng, 1987, Wang, 1988, Chang and Lim, 1988, Emanuel, 1987, Neelin et al., 1987, Hayashi and Miyahara, 1987, Hendon, 1988 among many others).

The results of the above diverse GCM experiments are generally consistent with the simple idea that the structure and eastward propagation of intraseasonal oscillations are due to the interaction between low-level moisture convergence and midtropospheric latent heat release from deep convection; the so-called mobile wave-CISK mechanism (Lindzen, 1974; Lau and Peng, 1987). However, a number of discrepancies still exist between model results and observations. One of the most serious difficulties is that almost all the GCMs produce oscillations with associated periods about $20-50 \%$ faster than the observed periods (20-30 days instead of 3060 days). Lau and Peng (1987), Sui and Lau (1989) and Takahashi (1987) have suggested that the propagation phase speed is sensitive to the level of maximum heating and that a lower level of heating will give rise to slower phase speeds of the oscillations. More recently, Lau and Shen (1988) have suggested that some degree of coupling with the ocean may be required to produce the observed phase speed of these oscillations. On the other hand, Hayashi and Golder (1986) have indicated that a distinct lowfrequency signal at 40 days can be obtained by simply increasing the spatial resolution of the GCM. Overall, it appears that all GCM simulations indicate that some form of a mobile wave-CISK mechanism is involved. Yet this mechanism is unable to explain the observed continual eastward propagation of the upper level wind field around the globe which occurs in spite of the lack of latent heat forcing over the eastern Pacific sector. Also, the most "realistic" simulation of the intraseasonal oscillations appears to be associated with a "turn-on" of latent heating over the maritime continent and tropical western Pacific, rather than a propagating heat source as has been observed over these regions. The aqua-planet experiments simulate rather well the combined eastward propagation of convection and circulation but fail to reproduce the stationary component of the oscillations. In reality, both the propagating and stationary components are present in these oscillations (Lau and Chan, 1985).

Obviously, much work is still needed in theory, GCM modeling and observations in order to fully understand the dynamics of intraseasonal oscillations. In view of the diverse model structure and physical parameterizations in different GCMs, there is a need to compare the results of the climatology of intraseasonal oscillations produced by various GCMs as they relate to the model characteristics. This will provide clues for explaining the model differences and hopefully new insights for improving the critical parameterizations needed to better simulate these oscillations. Archives of multi-year GCM climate integrations that now reside in various research laboratories provide a rich repository of information from which these inter-comparison studies can be conducted without further straining resources needed for extended integrations. In this paper, a modest step is taken in this direction. Obviously, the results of this work are not going to resolve, in any definitive way, the aforementioned problems. However, they will illuminate some key issues critical to present theories of the intraseasonal oscillation, and in doing so demonstrate a methodology by which model inter-comparison can be carried out in the future. For this paper, work had to be performed under the constraints that only a limited set of common variables had been saved, and that due to institutional changes and other factors, the integrations can not be repeated exactly or extended to pin down the causes of specific differences. However, based on the present results, some guidelines will be provided for further study of GCM intraseasonal oscillations. In the present paper, use will be made of the general terminology "intraseasonal oscillation" to refer to the 30-60 day or 40-50 day oscillation, or the Madden and Julian Oscillation (Madden and Julian, 1971, 1972), names which are also commonly used in the literature. They will be used interchangeably in this paper.

\section{Description of the GCMs and the Obser- vational Data}

There are three General Circulation Models (GCMs) whose output will be analyzed. They are referred to with the acronyms GLAS (Goddard Laboratory of Atmospheric Sciences), UCLA (Univer- 
sity of California, Los Angeles), and GLA (Goddard Laboratory for Atmospheres). Results from the global ECMWF analyses of 1984-1986 are also presented. All three GCMs are grid point models having a $4 \times 5$ degree latitude/longitude resolution with 9 layers in the vertical, and were integrated for at least two years (three in the case of the UCLA GCM) in a seasonal cycle mode. That is, a smooth seasonal cycle of insolation, including a diurnal variation, and all the other boundary conditions were introduced into the model integrations. The GLAS and GLA models use identical formulations of all physical processes, including radiation, boundary layer processes and cumulus convection. The parameterizations of physical processes in the UCLA GCM are completely different and are substantially more sophisticated. Each of the three GCMs employs a different scheme for computing finite-differences. They all use the vertical differencing of Arakawa and Suarez (1983).

The GLAS GCM is described in some detail by Randall (1982). This model employs a staggered grid (the so-called B grid), while the second order finite-difference scheme for horizontal momentum advection conserves momentum and kinetic energy. The cumulus parameterization scheme of Arakawa (1969, 1972), developed originally for a three-level GCM, was modified for use in a nine-level model by Somerville et al. (1974). This was accomplished by combining the lowest six layers pairwise into three layers for the simulation of cumulus convection, and restricting this process from extending into the uppermost three layers. This constraint (also present in the GLA GCM, to be described below) strongly influences the simulation of tropical intraseasonal oscillations. The boundary layer parameterization follows Deardorff (1972) with the assumption that the depth of the boundary layer is 500 meters everywhere. Vertical diffusion of momentum, sensible heat and moisture above the boundary layer is negligible. The long-wave radiation calculation $(\mathrm{Kr}-$ ishnamurthy, 1982) was performed once every five hours, but the heating rates were applied every 30 minutes, while short-wave radiation (Davies, 1982) was calculated every 30 minutes. The two-year integration studied in this paper was described in detail by Straus and Shukla (1988a, 1988b).

The GLA GCM is identical to the GLAS GCM in terms of all physical parameterizations, and differs from it only in terms of the numerical methods used. The GLA GCM utilizes a nonstaggered grid (the so-called A grid) with a quadratic (energy) conserving scheme of fourth order accuracy (Kalnay et al., 1983). Sixteenth order Shapiro filters are used in the horizontal dimensions in both the GLA and GLAS GCMs, although they are employed in different ways. With the staggered grid (GLAS GCM) the filter is not necessary to integrate the model, but is necessary to prevent a divergence of the solution when the nonstaggered grid (GLA GCM) is used (Randall, personal communication).

The UCLA GCM (described in detail in Randall, et al., 1985) uses a more recent parameterization of cumulus convection developed by Arakawa and Schubert (1974) and Lord et al. (1982). One distinctive feature of this GCM is that the top of the planetary boundary layer is a prognostic variable and acts as a coordinate surface. Mass sources and sinks for the planetary boundary layer are large scale divergence, turbulent entrainment and cumulus mass flux (Randall, 1979, 1984). The surface flux determination is that due to Deardorff (1972), and the radiation that of Schlesinger (1976). The horizontal differencing scheme uses a staggered grid, the socalled $\mathrm{C}$ grid. In this scheme, the nondivergent flow conserves kinetic energy, while potential enstrophy is conserved by the full flow. In addition, advection of vorticity and temperature are of fourth order accuracy.

While the global analyses prepared by the European Centre for Medium-Range Weather Forecasts (ECMWF) from 1980 were available, only the more recent analyses of 1984-1986 were chosen, because prior to 1984 the interannual variability of the divergent wind component was not reliable (Trenberth and Olson, 1988). In this study we worked primarily with five-day average fields for both the GCMs and the observations (analyses). In each case the time mean (over the entire length of the dataset) and the annual and semiannual harmonics were removed. These harmonics were calculated by leastsquares fitting for each separate year, followed by averaging over the individual years. For many of the diagnostics presented, the time series of the five-day means were further filtered by calculating the raw Fourier components, retaining only the periods between 30 and 60 days, and performing the inverse transform.

\section{General Features of Intraseasonal Oscilla- tions}

Following previous work, use is made of the 200 mb velocity potential as the primary field with which to detect the presence of the tropical intraseasonal oscillations. The geographical distribution of the variance of this field (filtered to retain only periods of 30-60 days) is shown in Fig. 1 for the three GCMs and the ECMWF analyses. The analyses (Fig. 1d) show that the strongest degree of 30-to-60 day variability occurs over the Indian Ocean, with large variability also seen over the western Pacific, extending across the equatorial Atlantic from South America to western Africa. This pattern is similar to the structure found in the observational studies of Lau and Chan $(1985,1986)$ using outgoing long-wave radiation (OLR). The GLAS GCM results (Fig. 1a) in- 

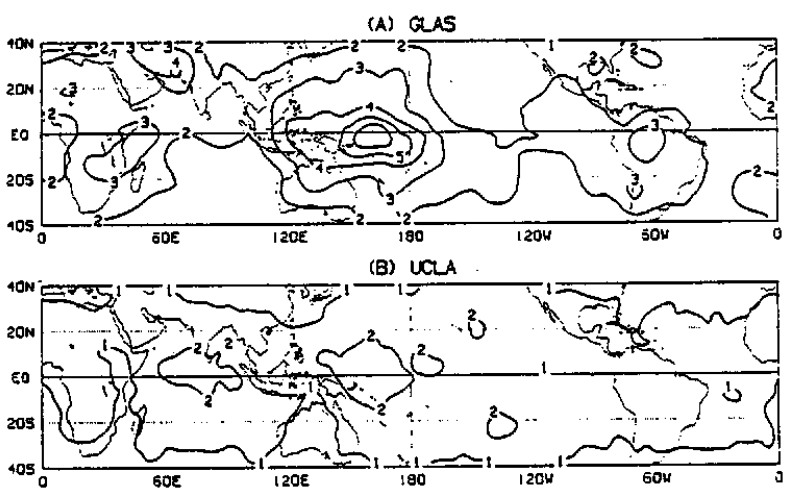

(C) GA

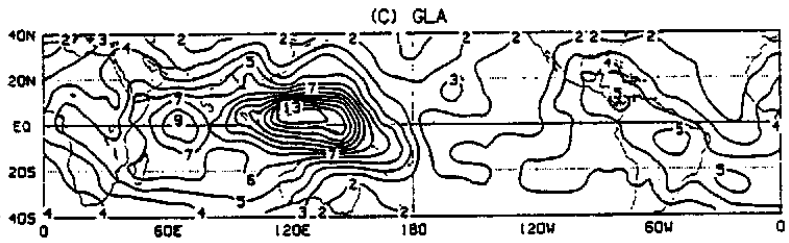

(D) ECMMF

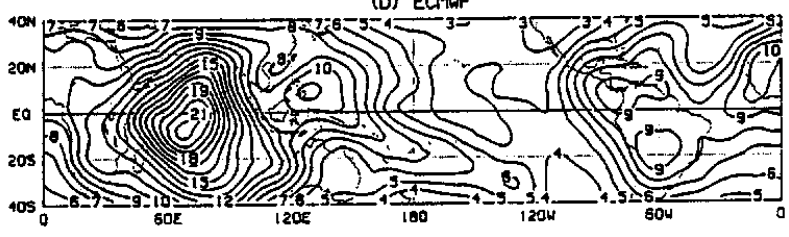

Fig. 1. Variance distribution of the filtered time series of five-day means of the 200 mb velocity potential. (a) GLAS GCM, (b) UCLA GCM, (c) GLA GCM, (d) ECMWF analyses. Contour interval is $1.0 \times 10^{12} \mathrm{~m}^{4} \mathrm{~s}^{-2}$

dicate enhanced variability over the western Pacific (although the maximum is shifted too far eastward by about 30 degrees) and over South America. The absence of a distinct maximum in variability over the Indian Ocean, the region where the observed signal is the strongest, should be noted. The magnitude of the simulated variability is quite weak compared to that observed. This is even more evident in the case of the UCLA results (Fig. 1b). The GLA GCM (Fig. 1c) is the most realistic in terms of the overall variance pattern, but the simulated variance is still not as strong as is observed, especially over the Indian Ocean. The simulated maxima in the western Pacific region in the GLAS and GLA models are closely related to the locations of the maxima in the mean diabatic heating in these GCMs. This weakness of the simulated 30-60 day oscillation is not unique to these particular models. Hayashi and Golder (1988), for example, find that the eastward propagating power at $\mathbf{4 5}$ days in their model is less than half of what was observed during 1979.

\section{a. $200 \mathrm{mb}$ velocity potential}

The presence of an eastward propagation is revealed by one-point correlation maps of the five day mean $200 \mathrm{mb}$ velocity potential. The correlations are computed from the filtered data with respect to
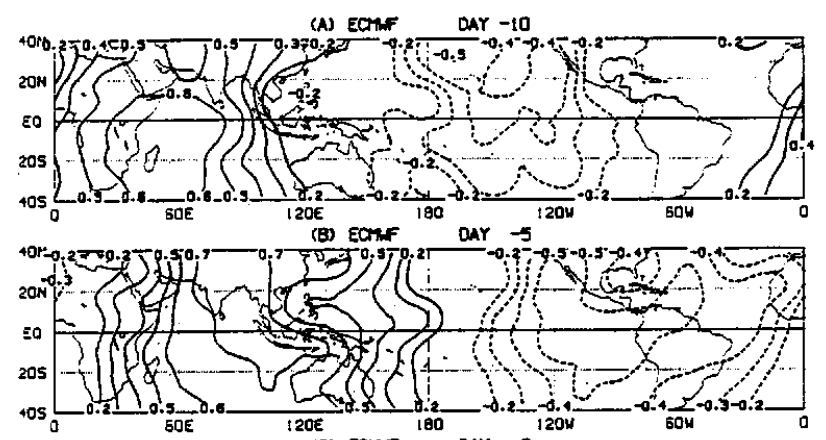
(c) ECMF DAY 0
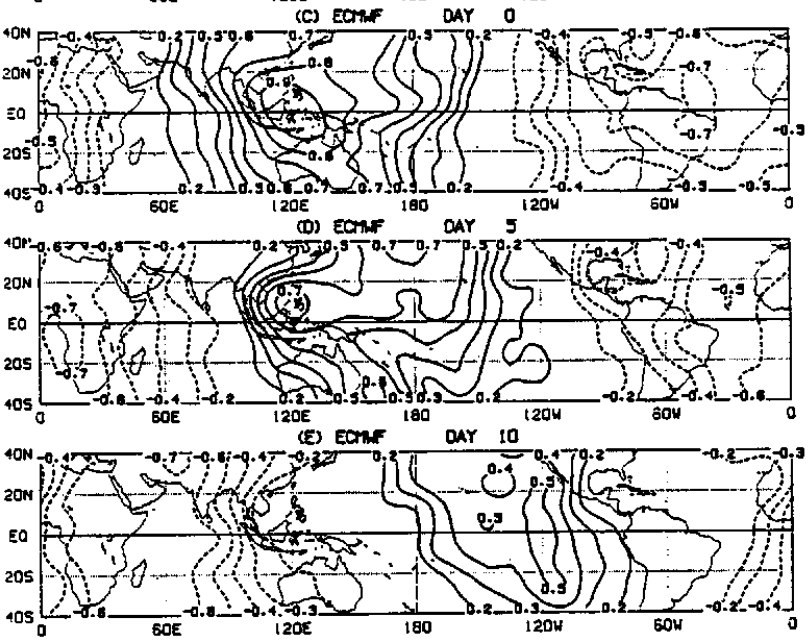

Fig. 2. One-point correlation of $200 \mathrm{mb}$ velocity potential five-day means using a base point of $120^{\circ} \mathrm{E}$ at the equator for the ECMWF analyses, with lags of (a) -10 days, (b) -5 days, (c) 0 days, (d) +5 days, and (e) +10 days. Correlations are computed from filtered data, with isolines drawn for every 0.1 for values exceeding \pm 0.1 .

a base point at the equator and $120^{\circ} \mathrm{E}$, as shown for the ECMWF analyses and the GCMs in Figs. 2-5. Lags of -10 to +10 days are considered. The propagation is quite evident in the observations, as shown in Fig. 2, as the planetary scale (zonal wavenumber one) structure gradually moves eastward, appears to become more stationary over the Indonesian region, and then accelerates over the central Pacific. This is consistent with the observed propagation of OLR and wind patterns for the 30-60 day oscillation (e.g. Lau and Chan, 1985; Knutson et al., 1986). Both theoretical analysis (Lau and Shen, 1988) and observational study (Gutzler and Madden, 1989) have suggested that the reduced phase speed of the disturbance may be related to moist Kelvin wave modes associated with enhanced convection over the warm SSTs of the western Pacific, and the increased phase speed further east associated with dry circulation modes due to the lack of convection over the cooler waters.

Figure 3 indicates that the GLAS GCM successfully simulates the eastward moving 30-60 day os- 

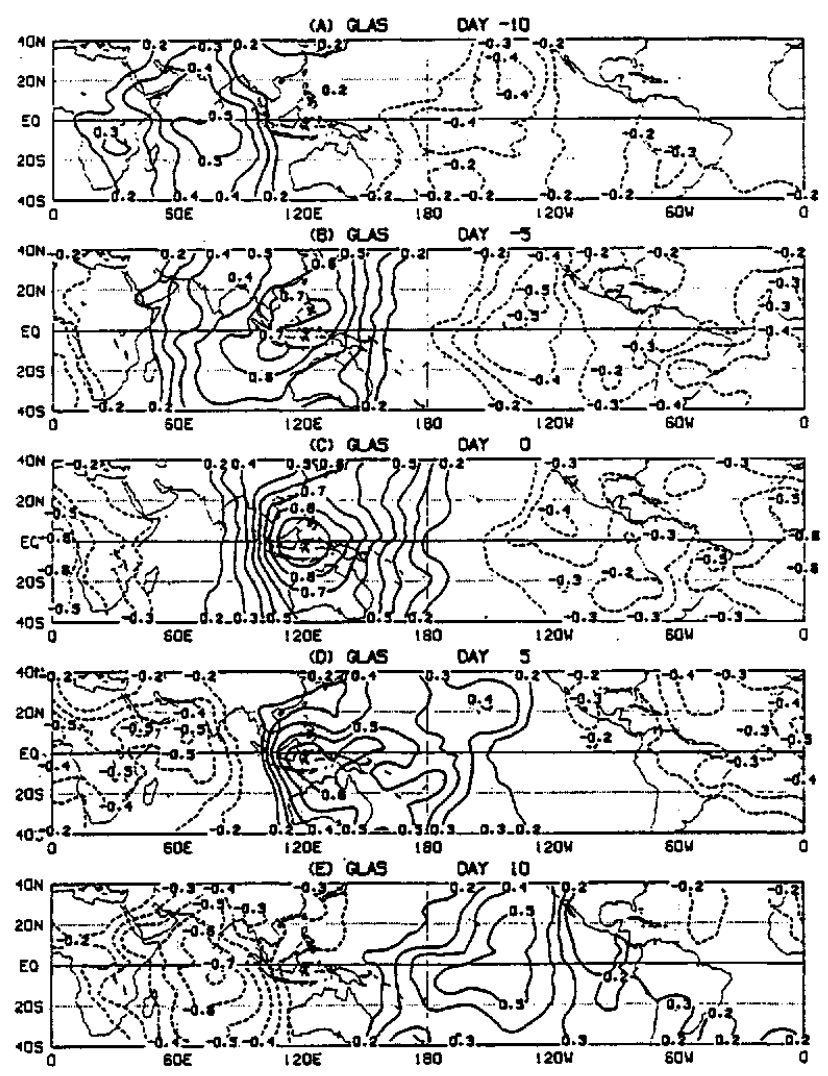

Fig. 3. Same as for Fig. 2, but for the GLAS GCM.
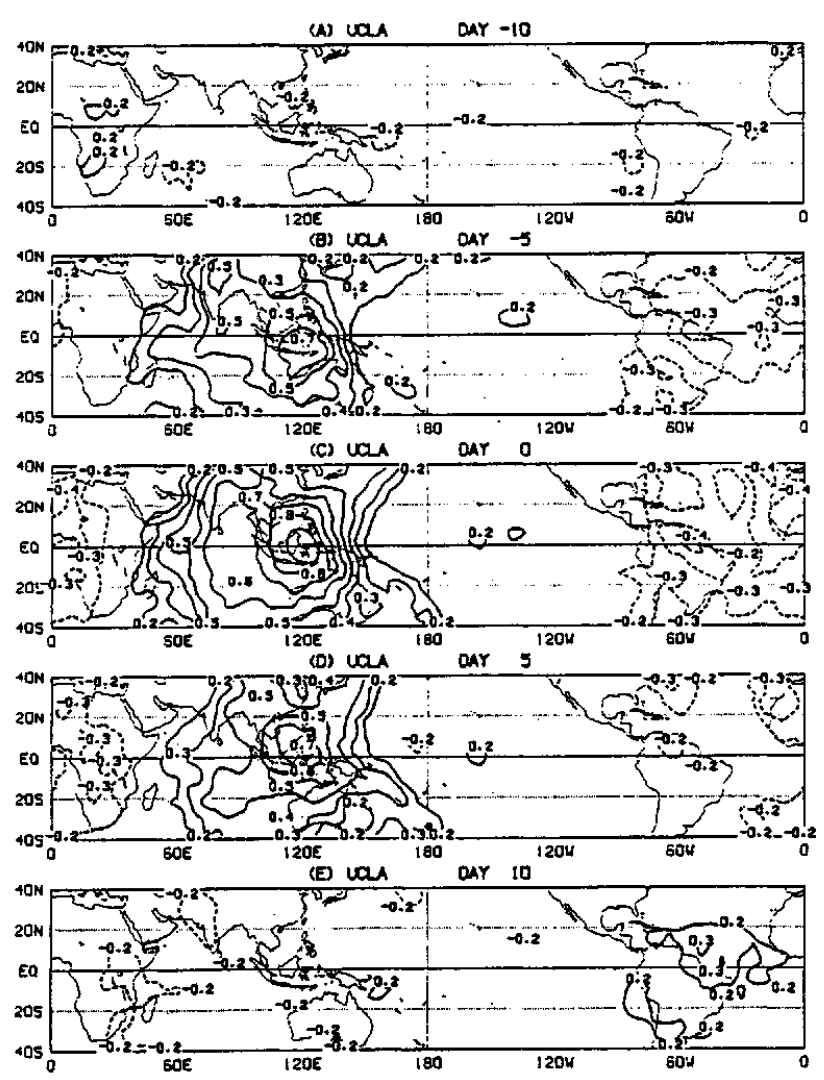

Fig. 4. Same as for Fig. 2, but for the UCLA GCM.
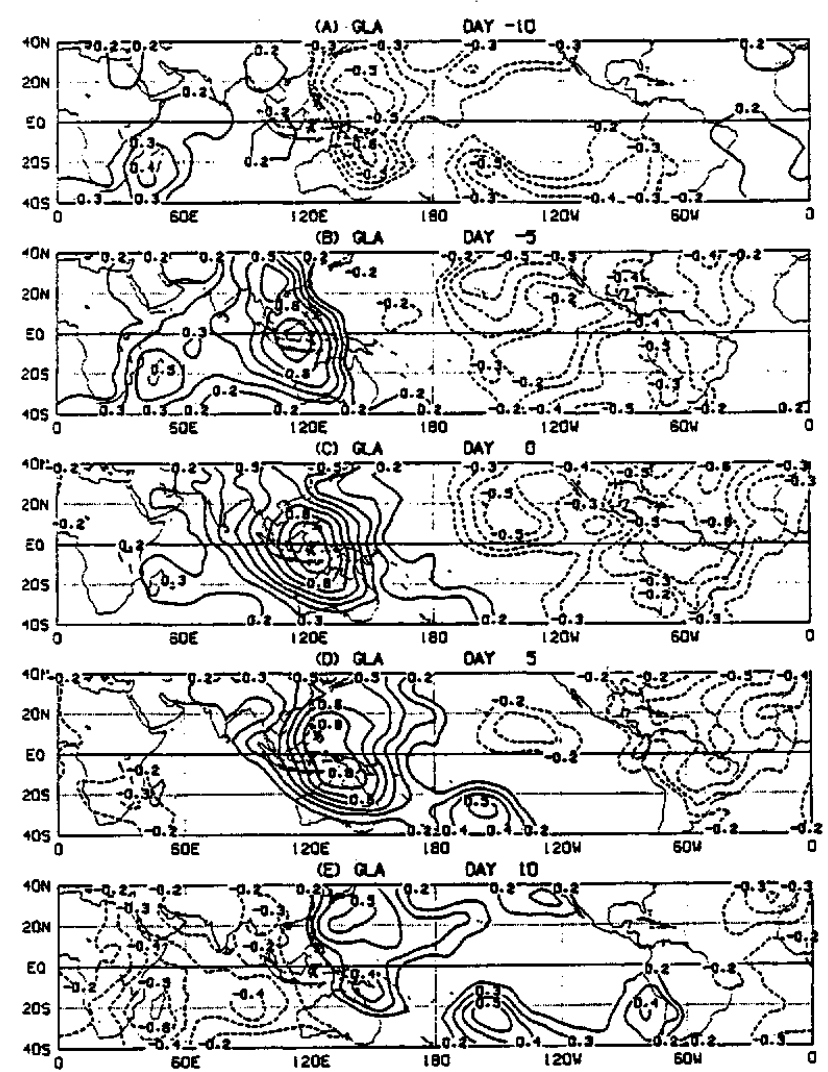

Fig. 5. Same as for Fig. 2, but for the GLA GCM.

cillation in the upper level divergent flow, including the acceleration of the wave after it passes the convectively active region. The one-point correlation maps of the UCLA GCM (Fig. 4) are much less realistic. Only local stationary signals are apparent. These signals disappear at \pm 10 days. For the GLA GCM (Fig. 5), the waves are nearly stationary at the base point in the tropics, but propagate eastward, dispersing into the higher latitudes of both hemispheres as the wave leaves the Indonesian region. Zonal wavenumber one, so evident in the correlation maps of the ECMWF analyses, is present in the results from the GLAS and GLA GCMs, but is much less obvious in the UCLA correlations.

The dominant space and time scales of the eastward traveling waves can be further elucidated by the use of wavenumber-frequency spectra. Since the spectra of the $200 \mathrm{mb}$ velocity potential at the equator are dominated by zonal wavenumber one, the frequency spectrum of only this component is presented in Fig. 6. The spectra were calculated using a Hamming window with a truncation point equal to half the total number of data points. The ECMWF spectrum is dominated by an eastward propagation with periods of 30 to 60 days, with peaks occurring at 30 and 60 days. The spectrum of the GLAS GCM is dominated by similar timescales (20 to 60 days) for eastward propagation, but the overall strength of the signal is significantly weaker than that ob- 

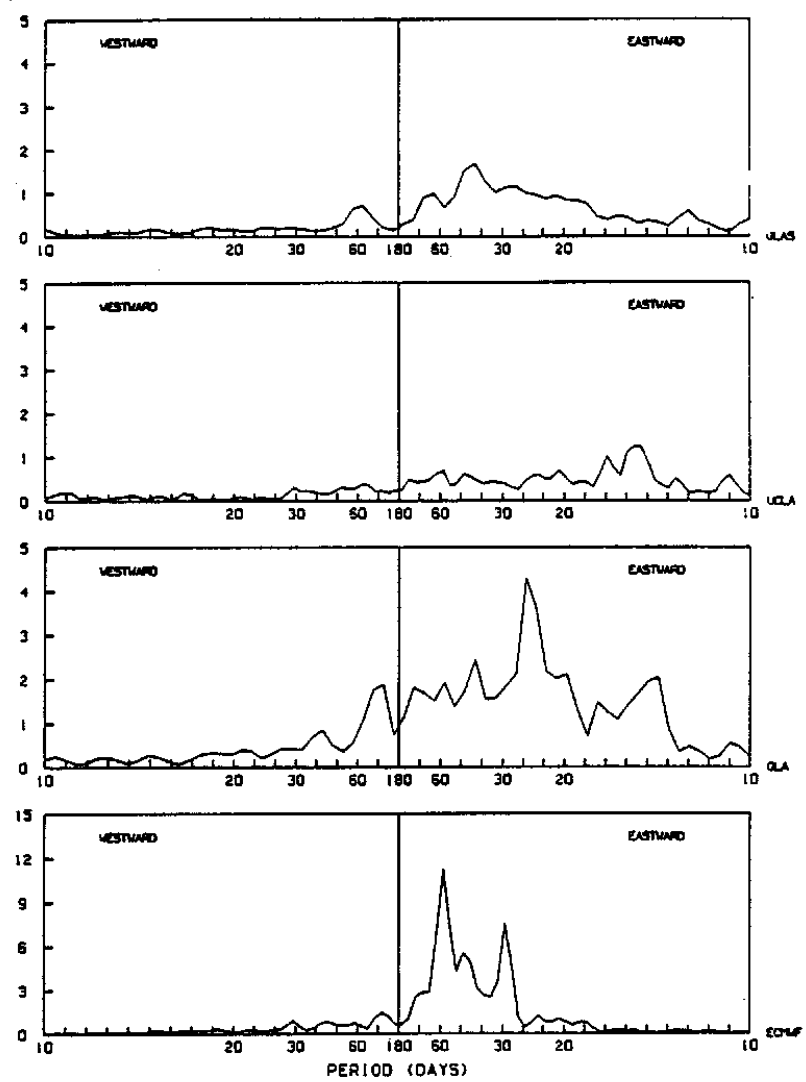

Fig. 6. Frequency spectra of $200 \mathrm{mb}$ velocity potential for zonal wavenumber one at the equator for GLAS, UCLA GLA GCMs and ECMWF analyses. Left (right) hand panels correspond to westward (eastward) propagating waves. Units are $10^{12} \mathrm{~m}^{4} \mathrm{~s}^{-2}$.

served, consistent with Fig. 3. There is no indication of a distinct oscillation in the 30 to 60 day range in the UCLA spectrum, although an eastward propagating peak near 15 days is suggested. The GLA spectrum, which has more power in the 30 to 60 day range than does the GLAS spectrum but less than that of the ECMWF analyses, is dominated by eastward moving waves with a peak around 20-30 days. Thus while the GLA spectrum shows more power in the 30-60 day range than the GLAS spectrum, the overall shape of the latter is more realistic.

\section{b. Vertical heating profile}

In a series of simple numerical experiments, Lau and Peng (1987) and Sui and Lau (1989) showed that the phase speed of the intraseasonal oscillation depends in a sensitive way on the vertical structure of convective heating. In order to define a diabatic heating associated with the oscillation in the GCMs, the total diabatic heating was composited on the basis of the time series of the filtered (five-day mean) velocity potential averaged over the western tropical Pacific $\left(10^{\circ} \mathrm{S}-10^{\circ} \mathrm{N}, 120^{\circ} \mathrm{E}-180^{\circ}\right)$. The composite includes only periods in which the velocity po-

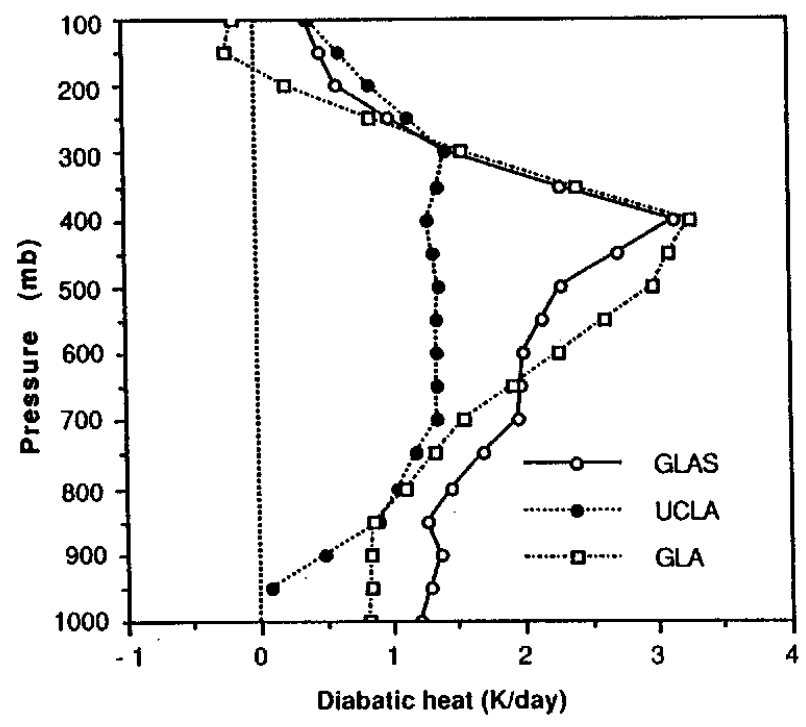

Fig. 7. Vertical profile of diabatic heating in the western tropical Pacific for the 30-60 day oscillation, based on the velocity potential in the region $10^{\circ} \mathrm{S}-10^{\circ} \mathrm{N}, 120^{\circ} \mathrm{E}-$ $180^{\circ}$ for GLAS, UCLA and GLA GCMs. See text for details.

tential exceeded one standard deviation below the sample mean (a minimum in the velocity potential is associated with divergence). The vertical profile of the composited total diabatic heatings averaged in the western tropical Pacific is shown for all three GCMs in Fig. 7. While the GLAS and GLA GCMs shown much stronger heating rates in the composite than does the UCLA GCM, there is another important difference in the vertical structure as well. The heating profile of the UCLA GCM is nearly uniform with height throughout much of the troposphere. In contrast, the other two models have their heating concentrated in the mid-troposphere, with a well-defined maximum near $500 \mathrm{mb}$ and small heating rates in the upper levels. ${ }^{1}$ Close inspection of Fig. 7 reveals that the region of largest heating in the GLAS GCM extends further downward than in the GLA GCM, so that while the latter model produces stronger heating at its peak (near $450 \mathrm{mb}$ ), the GLAS GCM heating is stronger at $700 \mathrm{mb}$.

According to simple theory by Sui and Lau (1989), the downward displacement of the GLAS GCM's heating profile in comparison to that of the GLA GCM should be reflected in the phase speed of the wave, with the latter (GLA) model having the faster phase speed. This is clearly seen in the spectra, as discussed above. The absence of an intraseasonal oscillation signal in the 30-60 day range in

\footnotetext{
${ }^{1}$ The form of the vertical profile of diabatic heating in the GLAS and GLA GCMs is a direct consequence of the manner in which the Arakawa cumulus convection scheme was implemented in these models. In particular, no convection was allowed to penetrate into the top three model layers.
} 
the UCLA GCM is attributed to the nearly uniform profile of vertical heating, which is due to excessive penetration of cumulus convection into the stratosphere. The Arakawa-Schubert cumulus parameterization allows the entrainment of environmental air into the cumulus clouds to vary over a wide range, with zero entrainment permitted. Tokioka et al. (1988) have shown that it is those cumulus clouds with no entrainment that penetrate so deeply and hence lead to the uniform vertical profile of heating. In experiments with a five-level aqua-planet model utilizing the same Arakawa-Schubert cumulus convection scheme, Tokioka et al. find only a fast eastward propagating wave with a period of 10 days, (which is to be compared with the period of 15 days we find in the UCLA model). However, modifying the cumulus parameterization by setting a lower nonzero limit to the entrainment of environmental air inhibits very deep convection, thereby leading to a 30-60 day oscillation in conjunction with a diabatic heating profile which has a distinct peak in mid-troposphere.

The longitudinal positioning of the strongest heating in the composites for each of the three GCMs coincides with the maximum in the velocity potential variance over the western Pacific for the given GCM seen in Fig. 1. This positioning also coincides with the longitude of maximum mean equatorial heating in each model, as deduced from maps of annual mean precipitation (not shown). This strongly suggests that the diabatic heating associated with the intraseasonal oscillation is triggered as the sector of the wave having low-level convergence passes over the region in which the model, in any case, tends to produce heating. Similar turn-on heating is found in a number of simulations of the $30-60$ day oscillation by GCMs which incorporate realistic lower boundaries (e.g. Lau and Lau, 1986; Geisler and Pitcher, 1988; Von Storch, et al., 1987). These results should be contrasted to the results of aquaplanet models (i.e., those with axisymmetric ocean or swamp lower boundaries), in which the precipitation follows the wave (Hayashi and Sumi, 1986; Swinbank et al. 1988; Lau, et al., 1988). The observational study of Lau and Chan (1985) showed evidence of both propagating and stationary components of convection associated with the 30-60 day oscillations.

\section{Detailed Structure Based on Composites}

In order to examine the detailed structure of the eastward propagating oscillation as it appears over the Indian Ocean and western Pacific sectors of the models and in the analyses, use is made of a compositing scheme which portrays the oscillation in a frame of reference moving with the wave. This scheme is a modified form of the one introduced by Lau et al. (1988), who studied the oscillation in a model with axisymmetric boundary conditions and so did not confine their attention to one particular sector. The first step of this scheme is to average each five-day mean velocity potential (from the filtered series) over $10^{\circ} \mathrm{S}$ to $10^{\circ} \mathrm{N}$, retaining only the first three zonal wavenumbers. This yields a smooth field which varies only in longitude. A translation $\mathrm{T}^{-}$is defined which maps the minimum of the smoothed velocity potential to the origin of longitude. A second translation $\mathrm{T}^{+}$, which maps the maximum to the origin, is also defined. The translations $\mathrm{T}^{-}$and $\mathrm{T}^{+}$are applied to whatever field (F) is to be composited, leading to the translated fields $\mathrm{F}-$ and $\mathrm{F}+$, respectively. The difference $\left(\mathrm{F}^{-}-\mathrm{F}^{+}\right)$ is taken and is averaged over all available pentads, regardless of season. In this average, each pentad is weighted by the longitudinal rms deviation of the field $F$, thus serving to emphasize periods when the oscillation is strong. This average weighted difference defines the oscillation in a frame of reference attached to the moving wave. The only modification introduced to the scheme of Lau et al. is to exclude from the average those periods when the minimum of the velocity potential did not fall in the sector $60^{\circ} \mathrm{E}-180^{\circ} \mathrm{E}$. This limits viewing the structure of the oscillation to the Indian Ocean-western Pacific sector.

This series of steps was repeated using temporal lags or leads, so that the data fields being composited and the longitude shifts used refer to different times. More specifically, only one longitudinal coordinate system is used for the various time lags of a given composite, and that system gives the position with respect to the arrival of the composited wave at zero lag. The non-zero lag composites show the fields some days before or after the arrival of the wave in this wave coordinate system. Further details are given in Lau et al. (1988).

\section{a. Horizontal structure of the wind}

In Figure 8, the upper level $(200 \mathrm{mb})$ composited tropical circulation is shown for the GCMs and the analyses at zero lag. The reader should keep in mind that the composite essentially follows the wave within the broad Indian Ocean-western Pacific region, so that longitude given in Fig. 8 and subsequent figures is a coordinate with respect to the center of the wave. The ECMWF analyses shown a very broad region of outflow dominated by the zonal component of the wind, with easterlies to the west and westerlies to the east of the wave center. The structure near the equator clearly resembles that of a Kelvin wave, with a possibly weak Rossby wave component. The $850 \mathrm{mb}$ flow (Fig. 9) is nearly the reverse of the $200 \mathrm{mb}$ flow. The upper-level GLAS GCM results also show that the outflow is dominated by the zonal wind component, although the simulated meridional winds along the equator are 

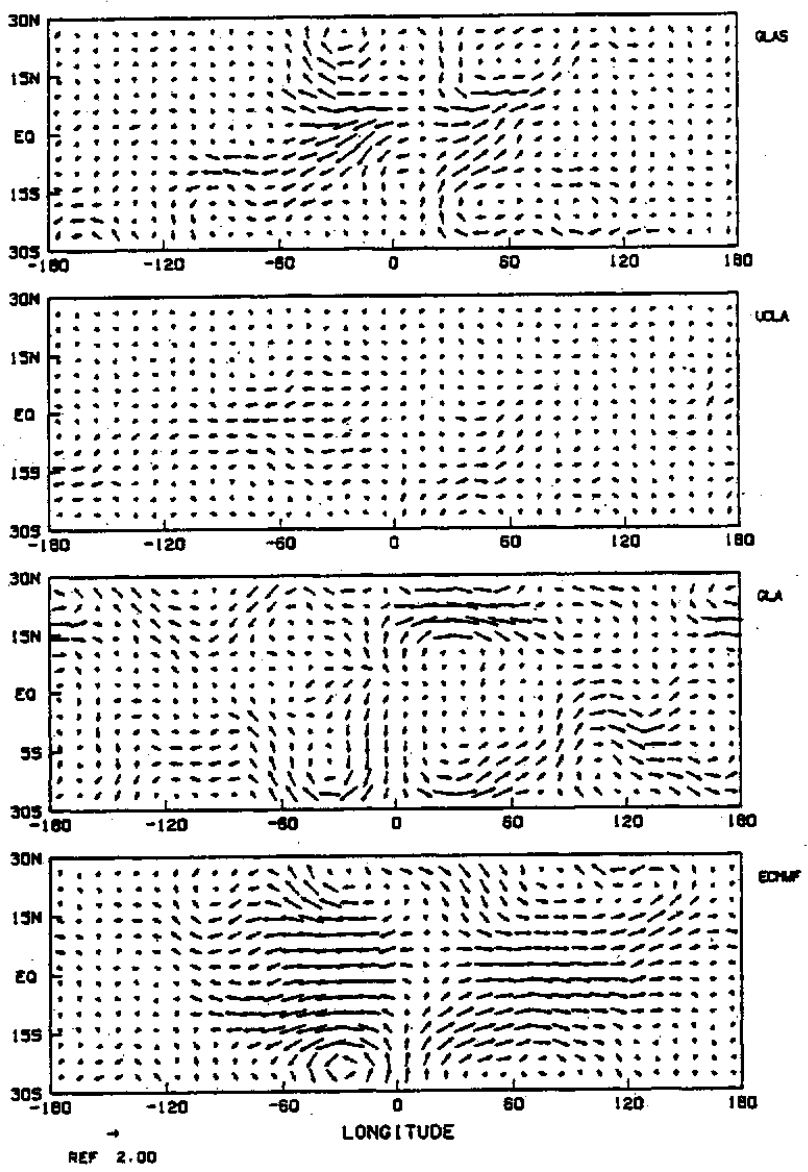

Fig. 8. Tropical $200 \mathrm{mb}$ flow for the zero lag Indian Ocean-western Pacific composite for GLAS, UCLA and GLA GCMs. Reference vector for $2 \mathrm{~m} / \mathrm{sec}$ is shown at the bottom.

too strong. At $850 \mathrm{mb}$ the GLAS GCM does simulate inflow, but contrary to the observations there are only very weak westerlies to the west of the reference longitude. Remarkably, the $200 \mathrm{mb}$ flow simulated by the GLA model is significantly different from both the GLAS model and the observations, with very weak flow along the equator and strong meridional outflow in the subtropical regions of both hemispheres. The GLA model also shows a more realistic inflow region at $850 \mathrm{mb}$, although the meridional extent of the inflow region is too narrow. The UCLA GCM shows only a weak circulation more or less in the same sense as the observations. The UCLA model does a slightly better job for the equatorial zonal wind at $850 \mathrm{mb}$, but elsewhere the circulation features are not very realistic.

\section{b. Vertical structure of the zonal component of the wind}

Due to the weak signal in the UCLA model, from here on focus will be centered on the comparison between the GLAS and GLA models. The evolution of the observed vertical structure of the oscillation can
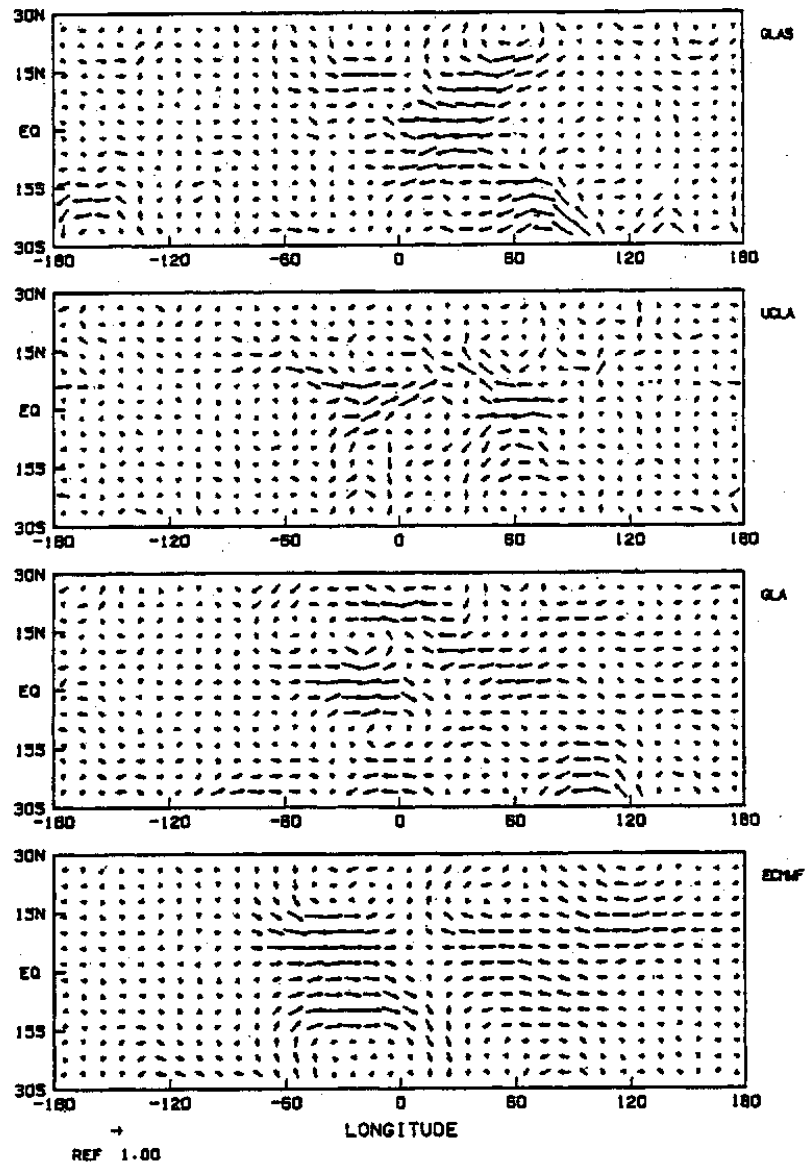

Fig. 9. Same as for Fig. 8 , but for $850 \mathrm{mb}$. Reference vector for $1 \mathrm{~m} / \mathrm{sec}$ is shown at the bottom.

be seen in the longitude-height sections of the composited zonal wind component along the equator for lags ranging from -10 days to +10 days (Fig. 10). The zero-lag composite shows the strongest low-level inflow at about $600 \mathrm{mb}$, and strongest outflow at $200 \mathrm{mb}$, with the transition occurring near $400 \mathrm{mb}$. The maximum low-level inflow in the zonal wind is clearly above the planetary boundary layer. This characteristic signal is generally confined to a longitudinal strip extending from $-60^{\circ}\left(60^{\circ}\right.$ west of the wave center) to $+90^{\circ}\left(90^{\circ}\right.$ east of the wave center $)$, although the upper level westerlies extend to $+120^{\circ}$. The low-level westerlies penetrate the center of the oscillation in the lowest layer. A weak westward tilt with height is apparent in the low-level inflow. The composites for the 5 days previous to and 5 days after the arrival of the wave have a structure which is generally similar to, but weaker than, the zero lag composite. The composites for +10 days and -10 days (which are nearly opposite) retain the upper level structure (but are shifted in longitude) of the zero-lag composite with a relatively weak lowlevel pattern. The evolution of the waves appears to have different stages characterized by different phase speeds. Using the upper level easterlies as a refer- 

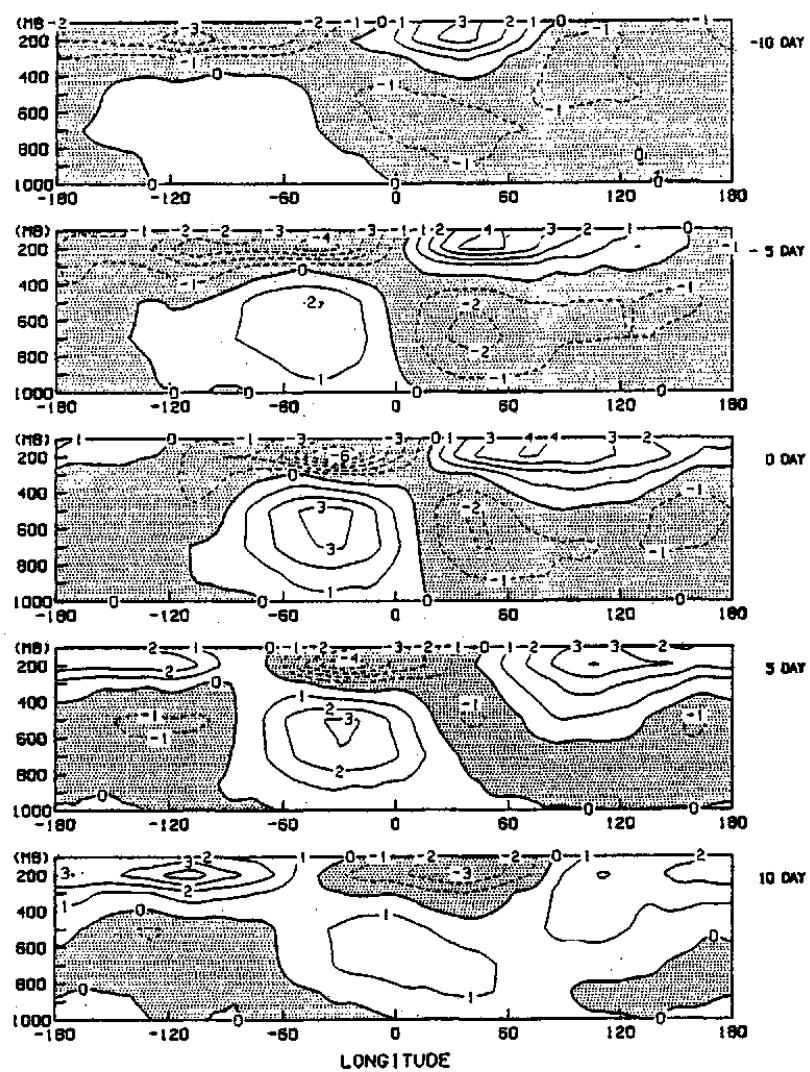

Fig. 10. Longitude-height sections of the $u-$ wind for the Indian Ocean-western Pacific composite along the equator (see text for details) from the ECMWF analyses, for lags of -10 days, -5 days, 0 days, +5 days, and +10 days. Units are $\mathrm{m} \mathrm{s}^{-1}$.

ence, the phase speeds are estimated to be about $10-12 \mathrm{~m} \mathrm{~s}^{-1}$ between \pm 10 days and \pm 5 days and $1-$ $2 \mathrm{~m} \mathrm{~s}^{-1}$ between the zero day and \pm 5 days. The westward tilt of the zonal wind perturbations with height is indicative of an eastward propagating unstable mode. While the tilt is very small at zero lag, when the wave is most intense, it becomes greater as the lead or lag increases. This is consistent with the theoretical expectation of these waves as they intensify and slow down (Lau and Peng, 1987). Murakami and Nakazawa (1985) found a similar westward tilt of the wave axis of eastward propagating zonal wind perturbations in observations.

The GLAS GCM zero-lag composite (Fig. 11) shows a realistic upper level configuration and a lowlevel easterly wind sector to the east of the wave center. The longitudinal extent of the pattern is somewhat less than is observed. The low-level westerly winds are too weak, as discussed above, although the westward tilt with height is well simulated in the upper troposphere above the $700 \mathrm{mb}$ level. The same is true of the \pm 5 days composites; the fields are realistic except that the observed westerly inflow is nearly absent in the model. The low-level
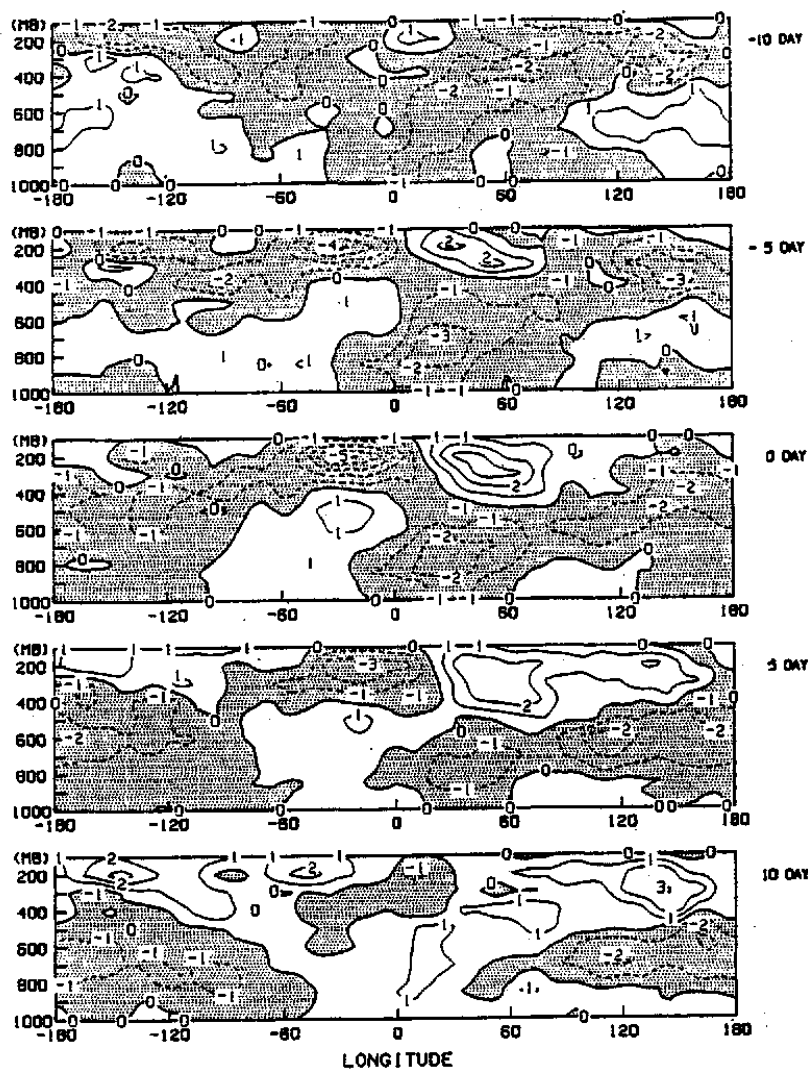

Fig. 11. As in Fig. 10, except for the GLAS GCM.

convergence is well above the planetary boundary layer, as is observed. The wind pattern is quasistationary between -5 and +5 days. There appears to be a faster eastward propagation for the far-field features between \pm 10 days and \pm 5 days. These are qualitatively in agreement with those observed.

While the zonal wind zero lag composite from the GLA GCM (Fig. 12) also indicates convergence below and divergence aloft, the convergent inflow is too strong and extends too high in the model atmosphere, with the maximum inflow occurring near $400 \mathrm{mb}$ and the transition from inflow to outflow being found above $300 \mathrm{mb}$. The $200 \mathrm{mb}$ winds are also too weak, as has been previously emphasized. The entire pattern is slightly broader in its east-west extent than in the GLAS model, but is not as broad as in the analyses. There is also a strong center of westerlies located at about $350 \mathrm{mb}$, at $+120^{\circ}$, to the east of the easterly inflow branch. While westerlies at this location are in fact observed, the strong divergence apparent in the GLA results near $+80^{\circ}$ at $350 \mathrm{mb}$ is not. The composites for lags of +5 and -5 days are very similar to that at zero lag. The westward tilt of phase with height is very pronounced at the zero lag and 5 day lag. The phase speed of the wave is quite uniform at about $3-4 \mathrm{~m} \mathrm{~s}^{-1}$.

Although the maximum inflow of the zonal wind perturbations surprisingly occurs in the mid- 

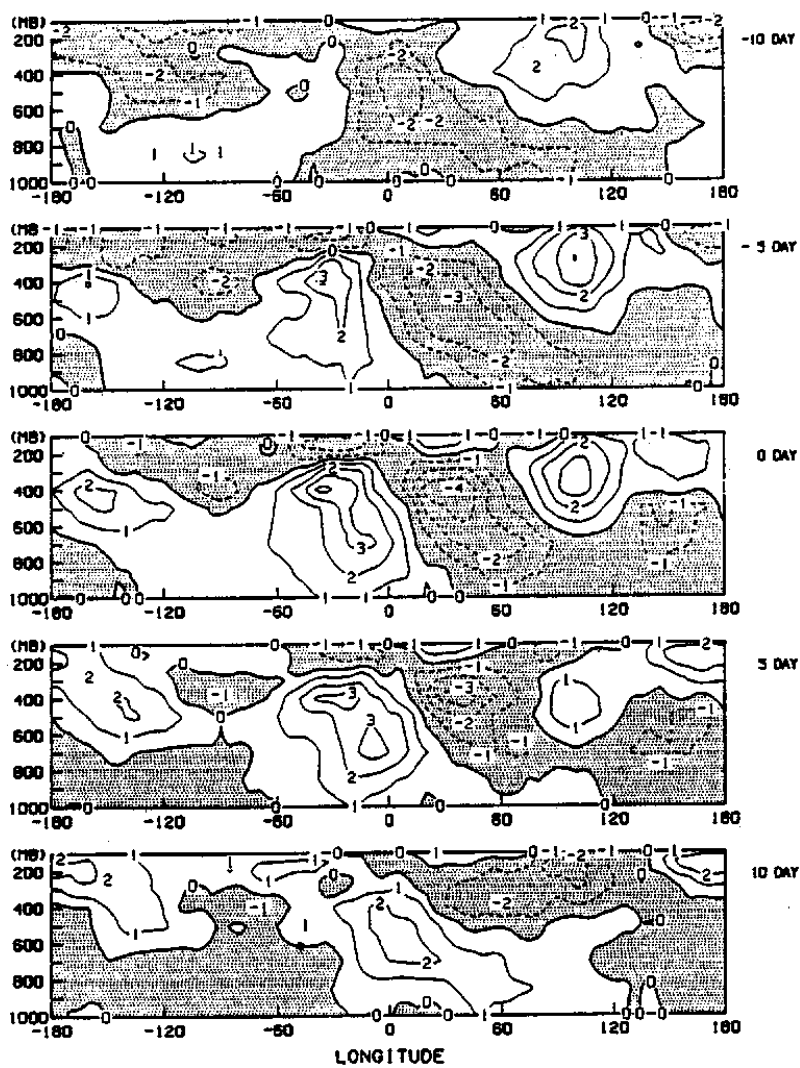

Fig. 12. As in Fig. 10, except for the GLA GCM.

troposphere in both the models and the analyses, the pattern retains the same sense (westerlies to the west of the wave center, easterlies to the east) down to the $1000 \mathrm{mb}$ level. Thus the wave composites are consistent with both the CISK and evaporation-wind feedback (Neelin et al., 1987) mechanisms. The fact that the convergence due to the zonal wind is not a maximum in the boundary layer may be an indication that the compositing scheme is not optimum, or it may be a consequence of a richer vertical structure to the wave than simply convergence in low levels and divergence in upper levels (Lau and Peng, 1987). Nothing in the CISK and evaporationwind feedback mechanisms requires a maximum in convergence at the lowest levels, only that such a convergence exist.

\section{c. Vertical structure of moisture}

The Indian Ocean-western Pacific composites of specific humidity from the ECMWF analyses are shown in Fig. 13. At low levels the moisture is greatest to the east (ahead) of the wave center at zero lag, while the driest air is behind the wave. The moist air extends all the way to the surface. Since the pattern tilts westward with height, the moistest air lies almost at the wave center at mid-levels. The composites for various time lags show basically similar patterns, although translated in the zonal di-
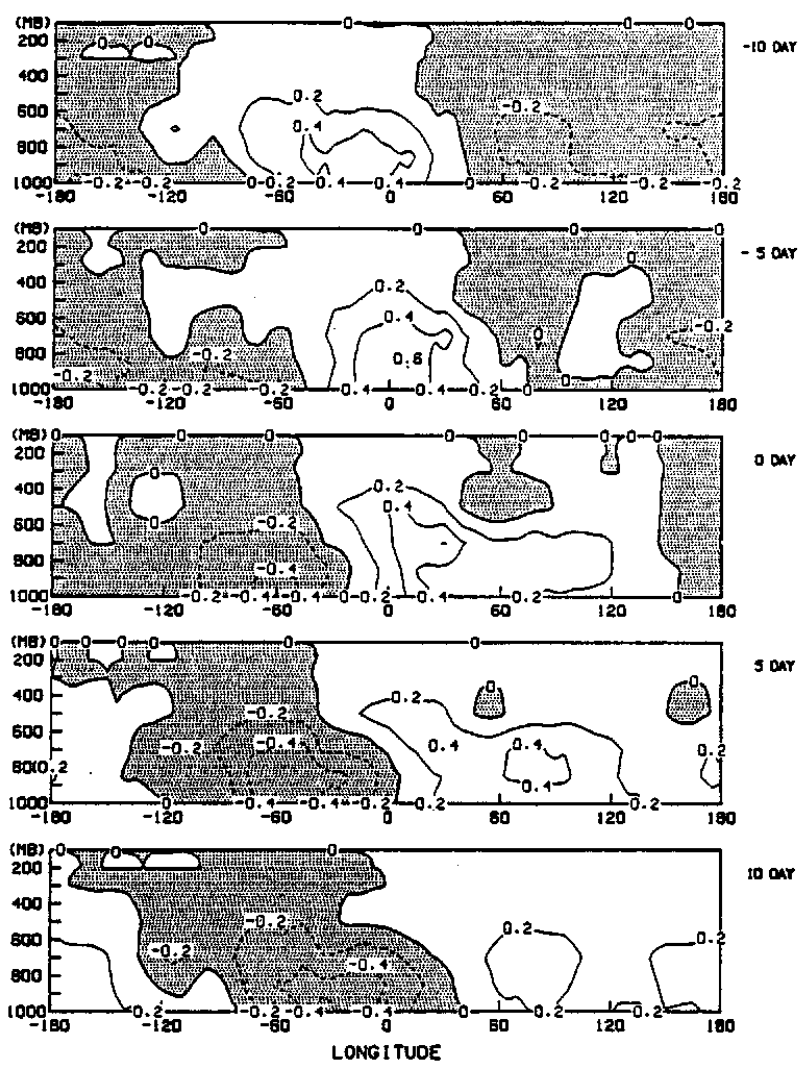

Fig. 13. Longitude-height sections of the specific humidity for the Indian Oceanwestern Pacific composite along. the equator (see text for details) from the ECMWF analyses, for lags of -10 days, -5 days, 0 days, +5 days, and +10 days. Units are $\mathrm{g} \mathrm{kg}^{-1}$.

rection. The relatively slow motion of the wave in the build-up phase (between -5 days and zero lag) compared to the subsequent large five day shift is evidence of the wave acceleration eastward of the region of maximum convection mentioned in Section 3. While the present compositing technique averages the structure of the wave across the very wide Indian Ocean/western Pacific sector, a remnant of this dramatic acceleration in the eastern portion of the sector survives the averaging process. The overall signature of the oscillation is even broader in the moisture field (around $200^{\circ}$ of longitude at zero lag) than was the case for the zonal wind. The above features suggest that there is a dramatic difference in the basic physics between the build-up and decay phases of these intraseasonal oscillations.

The large scale structure of the moisture field in the GLAS GCM composite at zero lag (Fig. 14) is generally realistic, although it is far noisier than that observed, and more narrowly confined in longitude. The low-level moisture maximum ahead of the wave center, the drying behind it and the westward tilt with height are all present, although the 

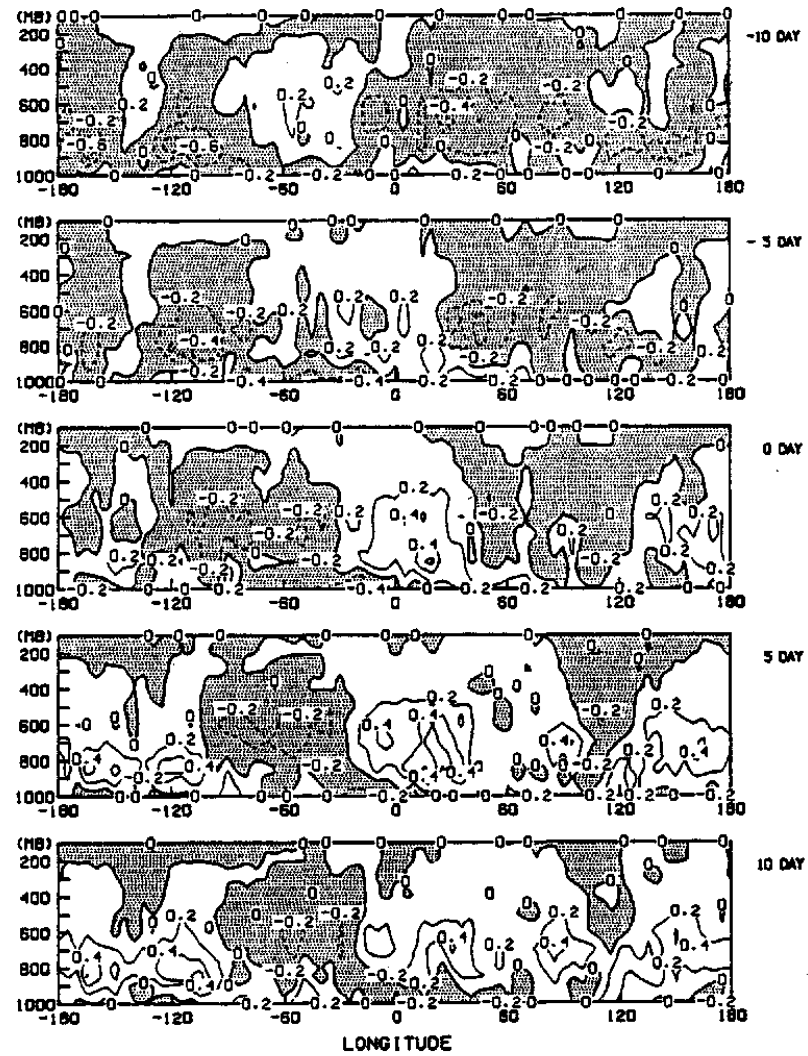

Fig. 14. As in Fig. 13, except for the GLAS GCM.

region of highest moisture content (greater than 0.4 $\mathrm{g} / \mathrm{kg}$ ) does not extend to the surface, as it does in the ECMWF analyses. While the -5 days lag composite correctly shows little shift in the position of the maximum from the zero lag composite, the shift seen in the observations at +5 days is absent in the model. Instead a new area of high moisture is seen, well ahead of the wave center. Smoothing of this simulated field would give a result in better agreement with the analyses at +5 days.

The equatorial specific humidity composite at zero lag for the GLA GCM (Fig. 15) is similar to that from the GLAS GCM down to about $850 \mathrm{mb}$, but near the surface the GLA GCM shows substantial drying. Apparently, moisture convergence in the boundary layer itself is not required to sustain the oscillation, convergence above the boundary layer being sufficient. The configuration of the moisture field in the longitudinal range of $-60^{\circ}$ to $+60^{\circ}$ is like that of the GLAS GCM, only shifted vertically upward. This upward displacement of the entire wave pattern was also seen in the zonal winds discussed above. The rapid movement of the low-level moist tongue seen in the ECMWF composites when going from 0 to 5 days is also reproduced in this model.

In general the vertical structure of moisture appears to be closely coupled with the zonal circulation in the equatorial plane, in both the observations and
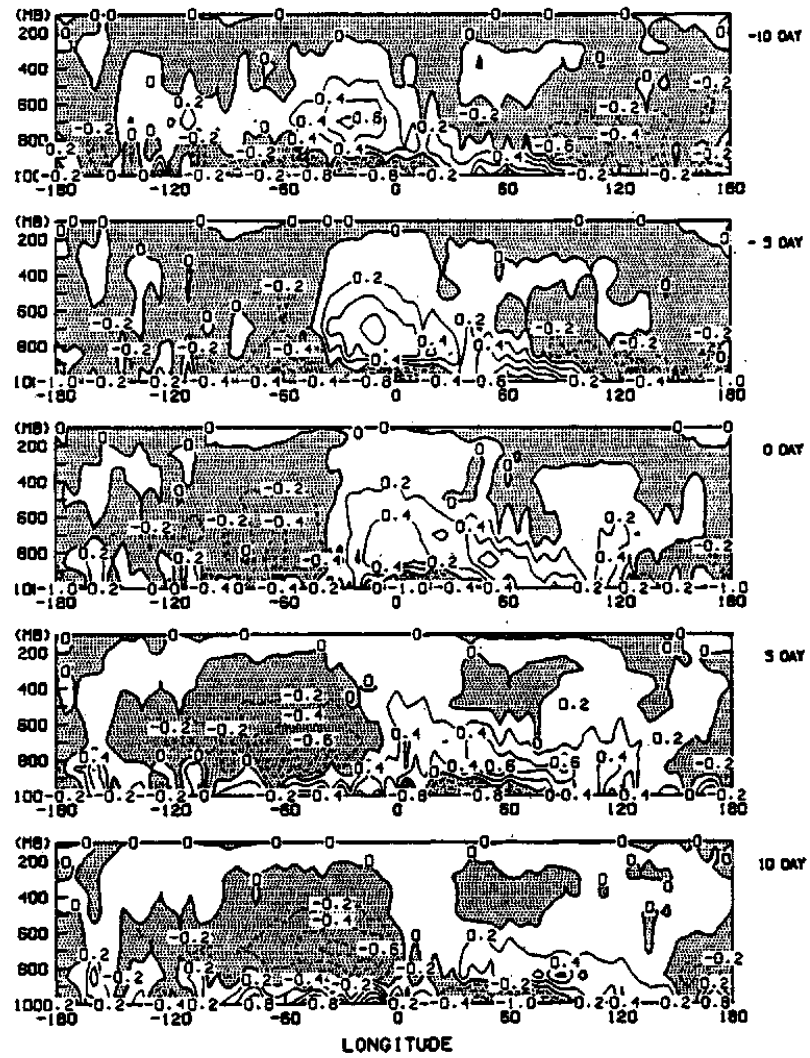

Fig. 15. As in Fig. 13, except for the GLA GCM

the GCMs. The zonal circulation supplies moisture to the east of the oscillation center in the convergence zone and leaves the dry zone behind the lowlevel westerlies, consistent with the presence of the evaporation-wind feedback mechanism for maintaining the oscillation. However, it is not clear that this mechanism is essential for the existence of the oscillation. For example, the composites of the oscillation in the study of Lau et al. (1988) with and without evaporation-wind feedback look nearly identical. It must be stressed that determining the cause of the oscillation from composited fields may be quite difficult, since the relevant maintenance terms in the thermodynamic and moisture budgets are likely to be very small residuals.

\section{Discussion and Conclusions}

A summary of the attributes for the simulation of tropical intraseasonal oscillations in the 30 to 60 day range by the various GCMs is compiled in Table 1 . Several features of interest emerge. Neither strong variability in the 30 to 60 day band nor an accurate geographical placement of such variability is enough to guarantee realistic propagation characteristics, as witnessed by the comparison of the GLAS and GLA GCMs. The former model does a reasonable job in simulating the propagation characteristics of the eastward propagating waves as they pass over con- 
Table 1. Summary of GCM Performance

\begin{tabular}{|c|c|c|c|}
\hline & GLAS GCM & UCLA GCM & GLA GCM \\
\hline \multicolumn{4}{|l|}{ Spectral Signal } \\
\hline Strength & weak & very weak & moderately weak \\
\hline Dominant periods & $\begin{array}{c}\text { realistic } \\
(30-60 \text { days })\end{array}$ & $\begin{array}{l}\text { far too short } \\
\text { (15 days })\end{array}$ & $\begin{array}{l}\text { slightly too short } \\
\text { (20-60 days) }\end{array}$ \\
\hline \multicolumn{4}{|l|}{ Spatial Signal } \\
\hline Pacific Ocean & $\begin{array}{l}\text { shifted eastward } \\
\text { moderately weak }\end{array}$ & $\begin{array}{c}? \\
\text { very weak }\end{array}$ & $\begin{array}{l}\text { realistic location } \\
\text { strong }\end{array}$ \\
\hline Indian Ocean & $\begin{array}{l}\text { shifted westward } \\
\text { very weak }\end{array}$ & $\begin{array}{c}? \\
\text { very weak }\end{array}$ & $\begin{array}{l}\text { realistic location } \\
\text { moderately weak }\end{array}$ \\
\hline \multicolumn{4}{|l|}{$\begin{array}{l}\text { Local Propagation } \\
\text { (Indonesian region) }\end{array}$} \\
\hline & realistic & too stationary & $\begin{array}{l}\text { disperses to high latitudes } \\
10 \text { days after passing } \\
\text { Indonesia }\end{array}$ \\
\hline \multicolumn{4}{|l|}{$\begin{array}{l}850 \mathrm{mb} \text { flow } \\
\text { (along the equator) }\end{array}$} \\
\hline & $\begin{array}{l}\text { westerly flow } \\
\text { west of reference } \\
\text { longitude weak }\end{array}$ & $\begin{array}{l}\text { reasonable } \\
\text { but noisy }\end{array}$ & realistic \\
\hline \multicolumn{4}{|l|}{$\begin{array}{l}200 \mathrm{mb} \text { flow } \\
\text { (along the equator) }\end{array}$} \\
\hline & reasonable & no signal & $\begin{array}{l}\text { zonal flow much too weak } \\
\text { meridional flow too strong }\end{array}$ \\
\hline $\begin{array}{l}\text { Vertical profile } \\
\text { of heating }\end{array}$ & $\begin{array}{l}\text { center above } 500 \mathrm{mb} \\
\text { extends to low levels }\end{array}$ & very deep & center above $500 \mathrm{mb}$ \\
\hline
\end{tabular}

vectively active regions of the Pacific, in spite of having a rather weak signal. The latter model, although exhibiting a stronger signal, tends to propagate the oscillation more towards higher latitudes after the wave passes the convective area. This appears to be related to the excessive meridional flow in the upper levels of the GLA model. In general, the placement of the convective areas (synonymous with the region of largest variability) is tied to the region where the GCM tends to produce its maximum vertically integrated diabatic heating (precipitation). The results presented here are subject to sampling errors which are hard to estimate, since the data from the two GCMs for which the 30-60 day oscillation is the strongest span only two simulated years. Hayashi and Golder (1988) examine six years from a longer integration, and found considerable interannual variability in the simulation of the $30-60$ day oscillation.

The overall vertical structure of the oscillation, as seen in the moving composites, is basically realistic in both the GLAS and GLA GCMs. The GLAS model does a slightly better job in capturing the different stages of the oscillation's development. The dry conditions near the center of the oscillation in the bottom layer of the GLAS and GLA GCMs are possibly related to insufficient moisture supply near the surface due to excessive drying of the lower troposphere by deep convection and/or a deficient wind-evaporation coupling at the surface. Particularly, the GLA GCM compensates for a lack of convergence in the planetary boundary layer by displacing the moisture convergence upward, which may be related to the relatively weak zonal flow and the excessive meridional flow at $200 \mathrm{mb}$. This suggests the need to improve the boundary layer of these models, with the possible inclusion of shallow convection.

There is a close relationship between the dominant periods that emerge from the spectrum and the overall vertical structure of diabatic heating associated with the Madden-Julian oscillation. This relationship, which associates deeper heating with more rapidly moving waves, can be understood from earlier theory and simulations. It explains why the UCLA GCM, with its very deep, nearly uniform heating profile shows oscillations in the 15 day range instead of the observed 30-60 day range. It also helps to understand how the greater heating in lower levels in the GLAS GCM (in comparison to the GLA GCM) leads to a more realistic (slower) phase speed for the disturbances in the GLAS GCM. The difference in heating profile between the GLAS and GLA GCMs also appears in composites of the diabatic heating in the moving frame of reference (not 
shown).

The physical parameterization that is responsible for the difference between the nearly uniform vertical profile of heating in the UCLA model and the vertical profiles of the GLAS and GLA models, which are peaked in mid-troposphere, is the cumulus convection scheme. The UCLA model's ArakawaSchubert scheme leads to excessive vertical penetration of the convection, as confirmed by Tokioka et al. (1988). The implementation of the earlier Arakawa cumulus scheme to the GLAS and GLA models explicitly prohibited the convection from penetrating into the top three model layers. It was this aspect of the parameterization that, while rather ad hoc, led to heating profiles consistent with more realistic phase speeds.

As has been emphasized, the GLAS and GLA GCMs differ from each other only in the numerical methods employed in solving the equations; the formulation of the physical parameterizations is identical in the two models. Another example of differences in simulation which can be attributed solely to numerical methods is given by Simmons et al. (1989). It would require further experimentation to determine unambiguously the mechanisms by which the differences in numerical techniques result in the observed differences of the tropical intraseasonal oscillations. Although we are not able to perform these experiments, our results strongly suggest the diabatic heating as one important mechanism. The parameterization routines of convection and other subgrid scale processes can be sensitive to the small-scale structure of the input fields on which they act, and it is precisely the small scales which are expected to differ when the numerics are changed. In particular the geographical location of the dominant tropical cumulus convection and its vertical profile are important in defining the regions of enhanced intraseasonal variability and its vertical structure. While the tropical mean flows of these two models do exhibit differences, the consequences of these differences to the intraseasonal oscillations presented here are likely to be secondary to the effects of diabatic heating. However, the extent of the easterlies in the time-mean flow may significantly affect the nature and strength of the tropicalextratropical teleconnections. This area is currently being investigated.

The models examined here have strongly preferred zones for diabatic heating, and the oscillation is forced as the region of large-scale ascent enters these preferred convective regions. Such a turn-on heating is observed in the intraseasonal oscillations produced by other GCMs with realistic lower boundaries. Finally, the present analysis is focused on the convective regime of the 30-60 day oscillations. $\mathrm{Ob}$ servations indicate that there is also a dry regime where the circulations seem to be maintained (with a faster phase speed) in the absence of convection. The reasons for the fixed nature of the heating in realistic models, as opposed to the highly mobile convection in models with idealized lower boundaries, and the maintenance of the circulation in the absence of convection during part of its journey around the globe and major concerns for future investigation.

\section{Acknowledgments}

This work was initiated while one of the authors (DMS) worked at the NASA/Goddard Space Flight Center. NASA support for DMS was continued at the University of Maryland through NASA grant NAG 5-1094. The support of NASA is gratefully acknowledged. In addition, the authors would like to thank Laura Rumburg for drafting the figures.

\section{References}

Arakawa, A., 1969: Parameterization of cumulus convection. Proc. WMO/IUGG Symposium on Numerical Weather Prediction, Tokyo, 26, November-4 December, 1968, Japan Meteor. Agency, IV, 8, 1-6

Arakawa, A., 1972: Design of the UCLA general circulation model. Numerical simulation of weather and climate. Technical report No. 7, Department of Meteorology, UCLA, Los Angeles.

Arakawa, A. and W.H. Schubert, 1974: Interaction of a cumulus cloud ensemble with the large-scale environment. Part I. J. Atmos. Sci., 31, 674-701.

Arakawa, A. and M.J. Suarez, 1983: Vertical differencing of the primitive equations in sigma coordinates. Mon. Wea. Rev., 111, 34-45.

Chang, C.-P. and H. Lim, 1988: Kelvin wave-CISK: A possible mechanism for the 30-50 day oscillations. $J$. Atmos. Sci., 45, 1709-1720.

Davies, R., 1982: Documentation of the solar radiation parameterization in the GLAS climate model. NASA Technical Memorandum 83961, 57 pp.

Deardorff, J.W., 1972: Parameterization of the planetary boundary layer for use in general circulation models. Mon. Wea. Rev., 100, 93-106.

Emanuel, K.A., 1987: An air-sea interaction model of intraseasonal oscillations in the tropics. J. Atmos. Sci., 44, 2324-2340.

Geisler, J.E. and E.J. Pitcher, 1988: On the representation of the 40-50 day oscillation in terms of velocity potential and streamfuction. J. Atmos. Sci., 45, 1850-1854.

Gutzler, D.S. and R.A. Madden, 1989: Seasonal variations in the spatial structure of intraseasonal tropical wind fluctuations. J. Atmos. Sci., 46, 641-660.

Hayashi, Y. and D.G. Golder, 1986: Tropical intraseasonal oscillations appearing in a GFDL general circulation model and FGGE data. Part I: Phase propagation. J. Atmos. Sci., 43, 3058-3067.

Hayashi, Y. and D.G. Golder, 1988: Tropical intraseasonal oscillations appearing in a GFDL general circulation model and FGGE data. Part II: Structure. J. Atmos. Sci., 45, 3017-3033. 
Hayashi, Y. and S. Miyahara, 1987: A three-dimensional linear response model of the tropical intraseasonal oscillation. J. Meteor. Soc. Japan, 65, 843-852.

Hayashi, Y.-Y. and A. Sumi, 1986: The 30-40 day oscillations simulated in an "aqua-planet" model. $J$. Meteor. Soc. Japan, 64, 451-467.

Hendon, H.H., 1988: A simple model of the 40-50 day oscillation. J. Atmos. Sci., 45, 569-584.

Kalnay, E., R. Balgovind, W. Chao, D. Edelmann, J. Pfaendtner, L. Takacs and K. Takano, 1983: Documentation of the GLAS fourth order general circulation model. Volume 1: Model documentation. NASA technical Memorandum 86064.

Knutson, T.R., K.M. Weickmann and J.E. Kutzback, 1986: Global scale intraseasonal oscillations of outgoing longwave radiation and $250 \mathrm{mb}$ zonal wind during Northern Hemisphere summer. Mon. Wea. Rev., 114, 605-623.

Krishnamurthy, V., 1982: The documentation of the Wu-Kaplan radiation parameterization. NASA Technical Memorandum 83926, 93 pp.

Lau, K.-M: and P.H. Chan, 1985: Aspects of the 40-50 day oscillation during the northern winter as inferred from outgoing longwave radiation. Mon. Wea. Rev., 113, 1889-1909.

Lau, K.-M. and P.H. Chan, 1986: Aspects of the 4050 day oscillation during the northern summer as inferred from outgoing longwave radiation. Mon. Wea. Rev., 114, 1354-1367.

Lau, K.-M. and L. Peng, 1987: Origin of low-frequency (intraseasonal) oscillations in the tropical atmosphere. Part I: Basic theory. J. Atmos. Sci., 44, 950-972.

Lau, K.-M. and S. Shen, 1988: On the dynamics of intraseasonal oscillations and ENSO. J. Atmos. Sci., 45, 1781-1797.

Lau, N.-C. and K.-M. Lau, 1986: The Structure and propagation of intraseasonal oscillations appearing in a GFDL general circulation model. J. Atmos. Sci., 43, 2023-2047.

Lau, N.-C., I.M. Held and J.D. Neelin, 1988: The Madden-Julian oscillation in an idealized general circulation model. J. Atmos. Sci., 45, 3810-3832.

Lindzen, R.S., 1974: Wave-CISK in the tropics. J. Atmos. Sci., 31, 156-179.

Lord, S.J., W.C. Chao and A. Arakawa, 1982: Interaction of a cumulus cloud ensemble with the large-scale environment, Part IV. The discrete model. J. Atmos. Sci., 39, 104-113.

Madden, R.A. and P.R. Julian, 1971: Detection of a 4050 day oscillation in the zonal wind in the tropical Pacific. J. Atmos. Sci., 28, 702-708.

Madden, R.A. and P.R. Julian, 1972: Description of global scale circulation cells in the tropics with a 4050 day period. J. Atmos. Sci., 29, 1109-1123.

Murakami, T. and T. Nakazawa, 1984: On the 40-50 day oscillation during the 1979 Northern Hemisphere summer. Part I: Phase propagation. J. Meteor. Soc. Japan, 62, 440-468.

Neelin, J.D., I.M. Held and K.H. Cook, 1987: Evaporation-wind feedback and low-frequency variability in the tropical atmosphere. J. Atmos. Sci., 44, 2341-2348.
Randall, D.A., 1979: The entraining moist boundary layer. Preprint volume. Fourth Symposium on Turbulence, Diffusion, and Air Pollution, Reno, Nevada, Amer. Meteor. Soc., 467-470.

Randall, D.A., 1982: Monthly and seasonal simulations with the GLAS climate model. Proc. Workshop on intercomparison of large-scale models used for extended range forecasts, Reading, ECMWF, 107-166 pp.

Randall, D.A., 1984: Buoyant production and consumption of turbulence kinetic energy in cloud-topped mixed layers. J. Atmos. Sci., 41, 402-413.

Randall, D.A., J.A. Abeles and T.G. Corsetti, 1985: Seasonal simulations of the planetary boundary layer and boundary-layer stratocumulus clouds with a general circulation model. J. Atmos. Sci., 42, 641-676.

Schlesinger, M.E., 1976: A numerical simulation of the general circulation of atmospheric ozone. Ph. D. dissertation, UCLA, 375 pp.

Simmons, A.J., D.M. Burridge, M. Jarraud, C. Girard and W. Wergen, 1989: The ECMWF Medium-Range Prediction Models. Development of the Numerical Formulations and the Impact of Increased Resolution. Meteor. and Atm. Phys., 40, 28-60.

Somerville, R.C.J., P.H. Stone, M. Halem, J.E. Hansen, J.S. Hogan, L.M. Druyan, G. Russell, A.A. Lacis, W.J. Quirk and J. Tenenbaum, 1974: The GISS model of the global atmosphere. J. Atmos. Sci., 31, 84-117.

Straus, D.M. and J. Shukla, 1988a: A comparison of a GCM simulation of the seasonal cycle of the atmosphere with observations. Part I: Mean fields and the annual harmonic. Atmosphere-Ocean, 26, 541-574.

Straus, D.M. and J. Shukla, 1988b: A comparison of a GCM simulation of the seasonal cycle of the atmosphere with observations. Part II: Stationary waves and transient fluctuations. Atmosphere-Ocean, 26, $575-607$.

Sui, C.-H. and K.-M. Lau, 1989: Origin of low frequency (intraseasonal) oscillations in the tropical atmosphere. Part II: Structure and propagation by mobile wave-CISK modes and their modification by lower boundary forcings. J. Atmos. Sci., 46, 37-56.

Swinbank, R., T.N. Palmer and M.K. Davey, 1988: Numerical simulations of the Madden and Julian oscillation. J. Atmos. Sci., 45, 774-788.

Takahashi, M., 1987: A theory of the slow phase speed of the intraseasonal oscillation using the wave-CISK. J. Meteor. Soc: Japan., 65, 43-49.

Tokioka, T., K. Yamazaki, A. Kitoh and T. Ose, 1988: The equatorial 30-60 day oscillation and the Arakawa-Schubert penetrative cumulus parameterization. J. Meteor. Soc. Japan., 66, 883-901.

Trenberth, K.E. and J.G. Olson, 1988: EMCWF global analyses 1979-1986: Circulation statistics and data evaluation. NCAR Tech. Note NCAR/TN$300+$ STR.

Von Storch, J.H., T. Bruns, I. Fischer-Bruns and K. Hasselmann, 1987: Principal oscillation pattern analysis of the 30-60 day oscillation in a GCM equatorial troposphere. Max-Planck Institute fur Meteorologie, Report No. 7 . 
Wang, B., 1988: Dynamics of tropical low-frequency waves: an analysis of moist Kelvin waves. J. Atmos. Sci., 45, 2051-2065.

\section{3 つの大循環モデルにおける熱帯季節内変動の構造の評価 Chung-Kyu Park \\ (NASA/GSFC)}

David M. Straus

(University of Maryland)

Ka-Ming Lau

(NASA/GSFC)

3 つの大循環モデル (GCM) の季節サイクル積分に現れる低周波振動が、ヨーロッパ中期子報センター (ECMWF) の解析と比較される。どのモデルも、緯度 3 度、経度 5 度、鉛直 9 層の同じ分解能である。

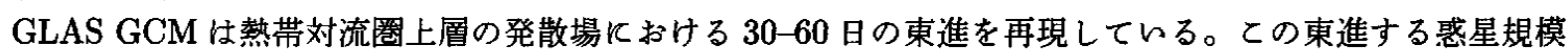
成分は、観測と同様にインドネシア域で定在的で、中部太平洋で加速している。GLA GCM ではての振動 は、波が対流域を離れるにつれて、両半球高緯度側に伝播する。UCLA GCMでは東進する振動ははっき りしない。200 mbの速度ポテンシャルの波数一周波数スペクトルは、どのモデルにおいても解析にくらべ て 30-60 日周期の東進成分は極端に弱い。GLAS GCM は 20-60 日周期が卓越し、GLA GCM では 20-30 日周期にピークを持つ。UCLA GCM には 15 日付近に弱い東進成分のピークがある。GCMでの卓越する 位相速度や熱分布の異なる鉛直構造は、顕熱と湿潤不安定との間の正のフィードバックからなる現行の理 論と一般的には一致している。

観測の重ね合わせパターンは、熱帯において、ケルビン波型構造が振動の中心付近で卓越しているとと を示している。再現された風の場は、非常によく観測と合っている。ただし南北成分は、とりわけGLA GCM で強すぎる。東西風と水蒸気の鉛直構造は、移動する波-CISK (Lau and Peng, 1987) が、これら GCM の季節内変動の維持構造として重要であるてとを示している。水蒸気の鉛直分布は、さらに、蒸発一 風フィードバック (Neelin, et al. 1987) が東進する熱帯波動の維持にある役割を演じているととを示唆し ている。GLAS GCM と GLA GCM との振動の構造の違いは、異なった数値計算方法の結果と思われる。 GCM は非断熱加熱にとって好都合な領域を持っており、李節内変動の上昇部が対流域を通過する際、熱 が放出されるよらになっている。

どのモデルも、ての振動の発達・消滅のさまざまな時期における詳細な時間経過をとらえるととはでを ていない。今回の結果は、ての振動をうまく再現するためには、境界首の湿潤過程の改良が重要であるて とを示している。 